Relations industrielles

Industrial Relations

\title{
Reviews on Industrial Relations
}

"Droit social"

Volume 5, numéro 5, février 1950

URI : https://id.erudit.org/iderudit/1023331ar

DOI : https://doi.org/10.7202/1023331ar

Aller au sommaire du numéro

Éditeur(s)

Département des relations industrielles de l'Université Laval

ISSN

0034-379X (imprimé)

1703-8138 (numérique)

Découvrir la revue

Citer cet article

(1950). Reviews on Industrial Relations: "Droit social". Relations industrielles / Industrial Relations, 5(5), 49-50. https://doi.org/10.7202/1023331ar

Tous droits réservés (C Département des relations industrielles de l’Université Laval, 1950
Ce document est protégé par la loi sur le droit d'auteur. L'utilisation des services d'Érudit (y compris la reproduction) est assujettie à sa politique d'utilisation que vous pouvez consulter en ligne.

https://apropos.erudit.org/fr/usagers/politique-dutilisation/ 


\title{
SOCIAL SENSE IN TORONTO
}

\author{
Mgr Ferdinand Vandry
}

I must further say that I am deeply interested in the social-mindedness or social sense that I notice in Toronto. We all know that social and economic life is changing a lot in the world. Everybody hears of new principles and doctrines taught to-day. Some people are unfortunately misled in thinking that the Catholic Church is fighting capitalism, preaching revolution and favoring communism. The truth is that the Church is doing nothing else that teaching the way to avoid the triumph of communism. She is teaching social justice and charity. That means that employers and workers must get closer together in a better understanding of their common problems. Workers must be made to understand that capital is necessary. Without capital, industry would vanish. But the employers must admit that their businesses should be conducted for the good of the community and not only for the profit of stockholders. Workers should be made satisfied and happy, because everybody on this earth has a right to his part of happiness. Make people happy and you destroy communism.

\section{REVIEWS ON INDUSTRIAL RELATIONS}

\section{"DROIT SOCIAL"}

\&DROIT SOCIAL » is a monthly review of about forty pages which studies problems of industrial interorganization and labour, as well as the new forms of economic life in their relations with the legal order. It draws the attention of its readers to the elements of this changing world which is building its domain in the border-lands of public and private law.

This publication usually contains a couple of articles prepared either by law professors chosen from the principal French universities, or by leading officials or functionaries of the Government. These works are of a nature to interest not only specialists in social legislation but also all those who follow closely the contemporary social and legal evolution.

It goes without saying that the greater number of studies published in \&DROIT SOCIAL 》 bear on French problems. But, we find there also some which treat certain facts of the social and legal situation in other countries.

CDROIT SOCIAL 》 is divided into two parts industrial organization and labour. It is in the first that we find the most advanced studies. It is ended always with a report on the economic situation consisting of a summary of the state of the economy at the moment of publication, industrial and agricultural activity, price and money levels, etc. This report is edited by Alfred Sauvy, director of the National Institute of Demographic studies and member of the Economic Council.
To have prosperity and happiness in our country capitalists must understand what their duty is and realize their money must not only profit themselves and the stockholders but also their employees. The Robert Simpson Company is a typical example of such social sense. If all the employers of Canada had the same spirit as Mr. Charles Burton, the President of Simpson Company, there would be nothing to fear from communism in this country.

It appears to me that more and more the large employers of Toronto realize their social obligations. They are largely interested in Canadian social and charitable organizations, such as the Red Cross which is a very meritorious institution. They are also interested in the welfare of their employees. Toronto is clearing the way to social justice and prosperity.

Those are some of the reasons why $I$ have to pay high tribute to the city of Toronto.

Extract from an address delivered at a meeting of Le club anglo-français de Simpson's on November 24,1949 .

The second part contains many headings such as « Jurisprudence récente en matière sociale », « Bibliographie », «Chronologie sociale française», and \& La situation sociale ». There are also, at times, a legislative report, appendices and documents. In this part one finds the texts of certain State orders-in-Council and abundant citations from judicial decisions, of which some are commented upon by a regular contributor to the Review. The three last numbers of «DROIT SOCIAL », i.e. those of June, July-August, and September-October, present a methodical bibliography on the Reform of the Enterprise. This bibliographical effort deals only with the sharing of personnel in the results of the activity of the enterprise and is limited to works and pamphlets published since 1944.

Since October, 1944, «DROIT SOCIAL 》 publishes a supplement entitled \& SECURITE SOCIALE ET PRESTATIONS FAMILIALES ». This aims at studying separately, but always in the spirit of \&DROIT SOCIAL 》, the totality of the problems posed by modern social security policies under the double aspect of indemnification for and prevention of the social risks - sickness, old age, labour accidents, occupational diseases, family responsibilities. The editor of this new review is Monsieur Paul Durand, professor in the Faculty of Law at Nancy and editor of «DROIT SOCIAL 》. On the editorial board, besides many law professors, are such important persons as Monsieur Pierre Laroque, director-general of social security; Doctor Jacques Parisot, president of the technical committee of Action sanitaire et sociale de la sécurité 
sociale »; François Perroux, director of the «Institut des sciences économiques appliquées ».

The subscription price for each of these Reviews is 1,600 francs. Those who are already subscribers to
«DROIT SOCIAL 》 benefit from a reduction of 200 francs for the subscription to \&SECURITE SOCIALE ET PRESTATIONS FAMILIALES 》.

Write: Librairie sociale et économique, 3, rue Souflet, Paris Ve.

STATISTICS AND INFORMATION

AWARDS BETWEEN NOVEMBER 1 AND 30, 1949

Employer

\begin{tabular}{|c|c}
$\begin{array}{c}\text { Affiliation of the } \\
\text { Labour Group }\end{array}$ & $\begin{array}{c}\text { Date of the } \\
\text { Award }\end{array}$ \\
\hline CGL & $4-11-49$ \\
AFL & $10-11-49$ \\
TLC & $11-11-49$ \\
CGL & $9-11-49$ \\
Ind. & $14-11-49$ \\
CGL & $17-11-49$ \\
CCCL & $15-11-49$ \\
Ind. & $30-11-49$ \\
CGL & $19-11-49$
\end{tabular}

S. Golstein.

Montreal Upholstering.

Dominion Tar \& Chemicals Co. Ltd.

City of Verdun - Firemen

City of Verdun - Policemen.

American Can Co..

Eastern Furniture Co.

St. Maurice Furniture Co. Ltd.

Bonner Leather Ltd \& Coyle Tanning Co.

ARBITRATION CASES ON NOVEMBER 30, 1949

\section{Employer}

M.E. Binz Co., Montmagny (grievances)

Bovry \& Staines Linoleum Ltd.

General Cigar Co. Ltd.

Asbestos Corporation Ltd.

Johnson's Co. Ltd.

Flinkote Mines

Singer Manufacturing Co.

Classon Knitting Mills Ltd.

Standard Shirt Co.

Fonderie Légaré

Quebec City Bakerie

Matthew Moody \& Sons Ltd.

Federal Electric

Manufacturing Co.

E.J. Maxwell Limited

Canadian Industries Limited (Brownsburg)

Drummondville and Victoriaville - Construction

City Furniture \& Frame Co.

Paramount Leather Goods

Empire Shirt, Louiseville

Atlas Bedding Ltd.

M.E. Binz Co. Ltd., Montmagny (renewal of agreement) Orange Crush \& Kik Co.

Hôtel-Dieu de Sherbrooke

Dubeau \& Frères, Joliette

J.-J. Joubert Ltée

A. Bélanger Ltée, Montmagny

Dominion Stores Ltd.

\section{Labour Group}

Syndicat national catholique du textile de Montmagny

Syndicat national des travailleurs de linoleum de Farnham

Tobacco Workers International Union, local 237 and 238

Syndicat national catholique des travailleurs de l'amiante d'Asbestos, de Johnson's Co. Ltd et de Flinkote Mines Ltd.

United Steel Workers of America, local 3764

Union des employés du vêtement de Sherbrooke

Union nationale du vêtement incorporée

Syndicat des employés de la Fonderie Légaré de Sherbrooke

United Steel Workers of America, local 4190

United Electrical Radio and Machine Workers of America, local 513

Association canadienne des travailleurs du bois, local 10

United Mine Workers of America, Canadian

Union internationale des remboureurs de l'Amérique du Nord, local 347

Union des ouvriers de la sacoche Syndicat national du vêtement de Louiseville Inc.

Union internationale des remboureurs de l'Amérique du Nord, local 302

Syndicat national catholique du textile de Montmagny

Transport Drivers Warehousemen and Helpers' Union, local 106

Association des employés du service hospitalier de Sherbrooke

Syndicat national catholique des travailleurs du bois de Joliette Inc.

Union ouvrière des employés de laiterie, local 973

Syndicat des travailleurs de la Fonderie de Montmagny Inc.

Retail Clerks International Association, local 486

\begin{tabular}{|c|c|}
\hline $\begin{array}{l}\text { Affiliation of } \\
\text { the Labour } \\
\text { Group }\end{array}$ & $\begin{array}{l}\text { President of the Council } \\
\text { of Arbitration }\end{array}$ \\
\hline CCCL & Justice Achille Pettigrew \\
\hline CCCL & Justice T.A. Fontaine \\
\hline AFL & Justice Jules Poisson \\
\hline CCCL & Justice Thomas Tremblay \\
\hline CIO & Jutice Armand Cloutier \\
\hline CCCL & G.D. Laviolette \\
\hline $\begin{array}{l}\text { CCCL } \\
\text { CCCL }\end{array}$ & $\begin{array}{l}\text { Justice Armand Cloutier } \\
\text { Justice Edouard Boisvert }\end{array}$ \\
\hline $\begin{array}{l}\text { CCCL } \\
\text { CGL } \\
\text { CIO } \\
\text { CIO }\end{array}$ & $\begin{array}{l}\text { Jean-Yves Gosselin } \\
\text { Justice Armand Cloutier } \\
\text { Me Ulric Laurencelle }\end{array}$ \\
\hline CLA Inc. & Me Roger Brassard \\
\hline CGL & Justice Alphonse Garon \\
\hline CCCL & Justice T.A. Fontaine \\
\hline AFL & Me André Montpetit \\
\hline $\begin{array}{l}\text { AFL } \\
\text { CCCL }\end{array}$ & $\begin{array}{l}\text { Justice T.A. Fontaine } \\
\text { Me Jean Gagné }\end{array}$ \\
\hline AFL & Justice Irénée Lagarde \\
\hline CCCL & Me Victor Trépanier \\
\hline AFL & Me André Montpetit \\
\hline CCCL & Justice Edouard Boisvert \\
\hline CCCL & Justice Guy Guilbault \\
\hline AFL & Justice Jules Poisson \\
\hline CCCL & Me Lucien Lortie \\
\hline AFL & Me André Montpetit \\
\hline
\end{tabular}

